\title{
Metabolic syndrome and C-reactive protein in bank employees
}

This article was published in the following Dove Press journal: Diabetes, Metabolic Syndrome and Obesity:Targets and Therapy 10 May 2016

Number of times this article has been viewed

\section{Monica Cattafesta' \\ Nazaré Souza Bissoli² \\ Luciane Bresciani Salaroli,3 \\ 'Postgraduate Program in Nutrition and Health, ${ }^{2}$ Postgraduate Program in Physiological Sciences, ${ }^{3}$ Postgraduate Program in Public Health, Department of Health Integrated Education, Federal University of Espírito Santo, Vitória, Espírito Santo, Brazil}

Correspondence: Luciane Bresciani Salaroli

Department of Health Integrated Education, Federal University of Espírito Santo, Marechal Campos Avenue, 1468 , Maruípe, Vitória, 29.040.090, Espírito Santo, Brazil

Tel +55 2733357223

$\mathrm{Fax}+552733357223$

Email lucianebresciani@gmail.com
Background: The ultrasensitive C-reactive protein (us-CRP) is used for the diagnosis of cardiovascular disease, but it is not well described as a marker for the diagnosis of metabolic syndrome (MS).

Methods: An observational and transversal study of bank employees evaluated anthropometric, hemodynamic, and biochemical data. CRP values were determined using commercial kits from Roche Diagnostics Ltd, and MS criteria were analyzed according to National Cholesterol Education Program's - Adult Treatment Panel III (NCEP/ATP III).

Results: A total of 88 individuals had MS, and $77.3 \%(n=68)$ of these showed alterations of us-CRP $(P=0.0001$, confidence interval [CI] 0.11-0.34). Individuals with MS had higher mean values of us-CRP in global measures $(P=0.0001)$ and stratified by sex $(P=0.004)$ than individuals without the syndrome. This marker exhibited significant differences with varying criteria for MS, such as waist circumference $(P=0.0001)$, triglycerides $(P=0.002)$, and diastolic blood pressure $(P=0.007)$, and the highest levels of us-CRP were found in individuals with more MS criteria. Conclusion: us-CRP was strongly associated with the presence of MS and MS criteria in this group of workers. us-CRP is a useful and effective marker for identifying the development of MS and may be used as a reference in routine care.

Keywords: C-reactive protein, bank employees, metabolic syndrome, inflammation mediators, occupational health

\section{Introduction}

Metabolic syndrome (MS) is a complex disorder that is characterized by a set of cardiovascular risk factors such as hypertension related to centripetal fat distribution and insulin resistance. ${ }^{1}$ The prevalence of MS is increasing in developed and developing countries as a result of genetic interactions with metabolic and environmental factors. ${ }^{2}$ There are no data on the Brazilian prevalence of MS, but several studies investigated MS in local situations or specific groups. A population-based study in Vitória, Espírito Santo, Brazil, observed an MS prevalence of $29.8 \% .^{3}$ The US demonstrated an increase in MS from 23\% to 34.5\% between 1988 and 2002. ${ }^{4}$

MS is directly related to increased cardiovascular risk and diabetes mellitus type 2 (DM 2), and MS is a growing source of concern worldwide, primarily because of its relationship to the increased risk of cardiovascular disease (CVD) and its close association with cardiovascular morbidity and mortality. ${ }^{5-7}$

The ultrasensitive C-reactive protein (us-CRP) is associated with the development of CVD, even mild elevations within the reference range. ${ }^{8,9}$ This protein has been used for the diagnosis of inflammatory and infectious states since the 1970 s. ${ }^{10,11}$ Moreover, 
studies indicate a positive correlation between serum CRP levels and the existence of MS or its components. However, few studies performed a deeper analysis of this relationship to determine differences between sex and age and estimate more accurate cutoff points for the use of CRP as a predictor of cardiovascular risk in MS patients.

The population of our study was evaluated and already published, and the results showed an MS prevalence of $17.2 \%(n=86,95 \%)$ in a group of 501 bank employees using National Cholesterol Education Program's - Adult Treatment Panel III (NCEP/ATP III) criteria. In these employees with MS, high levels of CRP $(4.4 \pm 4.7 \mathrm{mg} / \mathrm{dL}$, $P=0.001)$ were observed in employees with MS compared with those without MS. These factors demonstrate a high risk for CVD in this group. ${ }^{12}$

MS damages an individual's health and generates costly expenditures to public health. Therefore, the measurement of CRP levels may be an easily applied and reproducible method in clinical settings and epidemiological studies. ${ }^{13}$ Determinations of the relationship between CRP levels and the presence of MS may be useful to implement preventive strategies and rapid therapies and assist in the identification of MS. Therefore, this study evaluated the relationship of CRP levels with the presence of MS in bank employees in the city of Vitória, Espírito Santo, Brazil.

\section{Methods}

We performed an observational and cross-sectional study of employees of a government bank network in Vitória, Espírito Santo; anthropometric, hemodynamic, and biochemical variables were analyzed. The study was approved by the Research Ethics Committee (number 059/08) of the Center for Health Sciences, Federal University of Espirito Santo. Written informed consent was obtained from all of the participants.

Data were collected during 2008 and 2009, from employees of a state-owned banking network located in southeastern Brazil, who were aged between 20 and 60 years. Employees answered a questionnaire of investigative questions, and blood pressure data, anthropometric measurements, and blood samples were collected for subsequent biochemical analyses. Trained researchers conducted the entire study procedure.

Systolic blood pressure (SBP) and diastolic blood pressure (DBP) were measured using a OMRON 742H digital ${ }^{\circledR}$ (OMRON Healthcare Inc, Shanghai, People's Republic of China) following the protocol of the Joint National Committee on Prevention (2003). Blood pressure was classified according to the VI Guidelines on Hypertension. ${ }^{14}$ Waist circumference was measured at the natural waist using a metal inextensible tape (Sanny ${ }^{\circledR}$; American Medical do Brasil, Ltda, São Bernardo do Campo, Brazil). ${ }^{15}$

Biochemical tests were performed in an accredited network reference laboratory using the COBAS E601 analyzer (Roche Diagnostics International Ltd, Rotkreuz, Switzerland) to measure glucose levels, high-density lipoprotein cholesterol (HDL-c), triglycerides (TAG), and CRP. Blood samples were obtained by venipuncture in patients who fasted for 12 hours, and approximately $10 \mathrm{~mL}$ of blood was collected into tubes without anticoagulants (ie, dry tube). ${ }^{16}$

Data collection in the initial group revealed an MS prevalence of $17.2 \%(n=86,95 \%) .{ }^{12}$ The presence of MS was classified according to the NCEP/ATP III, which identifies the presence of MS when at least three of the following criteria are present: central obesity, measured as a waist circumference $(\mathrm{PC})>102 \mathrm{~cm}$ for men and $>88 \mathrm{~cm}$ in women; $\mathrm{SBP} / \mathrm{DBP} \geq 130 / 85 \mathrm{mmHg}$; fasting blood glucose $\geq 110 \mathrm{mg} / \mathrm{dL} ; \mathrm{TAG} \geq 150 \mathrm{mg} / \mathrm{dL}$; and HDL-c $<40 \mathrm{mg} / \mathrm{dL}$ for men and $<50 \mathrm{mg} / \mathrm{dL}$ for women. ${ }^{17}$ The use of medication for regulation of blood pressure, and of lipids and blood glucose levels should also be considered in the diagnosis of MS. ${ }^{6}$ This methodology is recommended by the I Brazilian Guidelines for Diagnosis and Treatment of Metabolic Syndrome. ${ }^{1}$

Patients who reported having an infection did not have their blood collected initially, but the collection was extended by 2 weeks until the infection was cured. Patients with colds, flu, emphysema, bronchitis, arthritis, or CRP values above $10 \mathrm{mg} / \mathrm{dL}$ were excluded from the study. The latter patients may indicate transient changes in CRP levels because of an infection and/or an acute inflammatory condition. ${ }^{6}$ Therefore, data were initially collected from 521 bank employees. Fiftyeight of these employees were excluded because they had a chronic infection, 26 employees had CRP values $>10 \mathrm{mg} / \mathrm{dL}$ and 25 employees did not undergo evaluations of biochemical and anthropometric tests that allowed their classification according to the criteria for MS, for a total of 412 employees with valid data.

The us-CRP classification was assigned for altered usCRP values $>1 \mathrm{mg} / \mathrm{dL}$, and adequate CRP was assigned for values $\leq 1 \mathrm{mg} / \mathrm{dL}$, according to the Centers for Disease Control and the American Heart Association (Atlanta, USA, 2003). Controls exhibited the following classifications, which were also recommended by the American Heart Association: low risk $<1 \mathrm{mg} / \mathrm{dL}$; medium risk: $1-3 \mathrm{mg} / \mathrm{dL}$; and high risk: $>3-10 \mathrm{mg} / \mathrm{dL} .{ }^{18}$ 
The Kolmogorov-Smirnov normality test was initially applied to determine parametric and nonparametric variables. The us-CRP values underwent logarithmic transformation to reduce the asymmetry of the distribution using the natural logarithm of us-CRP and the Pearson correlation coefficient.

We used frequency and measures of central tendency to characterize the sample. We used the mean \pm standard deviation for symmetric distributions and median and interquartile ranges for asymmetric distributions. Comparisons of different categories were performed using the chi-square test $\left(\chi^{2}\right)$. Student's $t$-test was used for parametric variables, and the Mann-Whitney $U$ test was used for nonparametric variables. In all cases, $P$-values $<0.05$ were considered significant. The statistical package SPSS for Windows version 17.0 (SPSS Inc., Chicago, IL, USA) was used for all analyses.

\section{Results}

A total of 217 (52.7\%) of the 412 individuals who participated in the study were male, and 195 patients (47.3\%) were female. A total of $336(81.6 \%)$ patients were aged $<50$ years. The sample group had high levels of education; $76 \%$ $(n=313)$ had a college degree and/or postgraduate degree in an upper-middle socioeconomic class, with a predominance of socioeconomic class $\mathrm{A} / \mathrm{B}(\mathrm{n}=230,55.8 \%)$. Socioeconomic class is classified on a scale ranging from A (highest) to E (lowest) using the Economic Classification Criterion of Brazil, which assesses the presence and quantity of some household items and the level of education of the head of the household Most employees were Caucasian ( $n=246$, $59.7 \%)$, lived with a partner $(\mathrm{n}=260,63.3 \%)$, and worked 8 hours or more daily $(n=244,59.2 \%)$. A total of $291(70.6 \%)$ of the bank employees studied, reported consuming or have already consumed an alcoholic beverage, and men reported the most consumption $(P=0.000)$. Tobacco use in females was higher $(P=0.002)$, but $67.6 \%(\mathrm{n}=278)$ of the group did not use tobacco. Most individuals $(52.2 \%, \mathrm{n}=215)$ were physically active, with no difference between sexes (Table 1).

A total of 251 individuals (60.9\%) showed elevated us-CRP levels, and 161 (39.1\%) individuals had adequate us-CRP. These individuals with elevated us-CRP levels, revealed that 96 (23.3\%) had high risk, $155(37.6 \%)$ had moderate risk, and 161 (39.1\%) had low risk.

The mean value of us-CRP was $2.176 \pm 2.12 \mathrm{mg} /$ $\mathrm{dL}$, with a minimum of $0.01 \mathrm{mg} / \mathrm{dL}$ and a maximum of $9.7 \mathrm{mg} / \mathrm{dL}$. The variable was not normally distributed, and a log-transformation was performed.
Table I Characteristics of the samples of the bank employees

\begin{tabular}{|c|c|c|c|c|c|c|c|}
\hline \multirow[t]{2}{*}{ Characteristics } & \multicolumn{2}{|c|}{ Male } & \multicolumn{2}{|c|}{ Female } & \multicolumn{2}{|c|}{ Total } & \multirow[t]{2}{*}{$P$-value } \\
\hline & 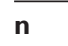 & $\%$ & $n$ & $\%$ & $\mathbf{N}$ & $\%$ & \\
\hline Age & & & & & & & 0.002 \\
\hline$<50$ years old & 165 & 76.0 & 171 & 87.7 & 336 & 81.6 & \\
\hline$\geq 50$ years old & 52 & 24.0 & 24 & 12.3 & 76 & 18.4 & \\
\hline Education & & & & & & & 0.176 \\
\hline Until high school & 58 & 26.7 & 41 & 21.0 & 99 & 24.0 & \\
\hline Higher education & 159 & 73.3 & 154 & 79.0 & 313 & 76.0 & \\
\hline Race/color & & & & & & & 0.605 \\
\hline White & 127 & 58.5 & 119 & 61 & 246 & 59.7 & \\
\hline Non-white* & 90 & 41.5 & 76 & 39 & 166 & 40.3 & \\
\hline Marital status** & & & & & & & 0.0001 \\
\hline Living with life partner ${ }^{\ddagger}$ & 157 & 72.4 & 103 & 53.1 & 260 & 63.3 & \\
\hline $\begin{array}{l}\text { Not living with life } \\
\text { partner }^{\S}\end{array}$ & 60 & 27.6 & 91 & 46.9 & 151 & 36.7 & \\
\hline Socioeconomic class ${ }^{\dagger}$ & & & & & & & 0.712 \\
\hline $\mathrm{A} / \mathrm{B}$ & 123 & 56.7 & 107 & 54.9 & 230 & 55.8 & \\
\hline$C / D$ & 84 & 43.3 & 88 & 45.1 & 182 & 44.2 & \\
\hline Working hours & & & & & & & 0.484 \\
\hline$<6$ hours/day & 85 & 39.2 & 83 & 42.6 & 168 & 40.8 & \\
\hline$\geq 8$ hours/day & 132 & 60.8 & 112 & 57.4 & 244 & 59.2 & \\
\hline $\begin{array}{l}\text { Alcohol } \\
\text { consumption }\end{array}$ & & & & & & & 0.0001 \\
\hline $\begin{array}{l}\text { Drinks or has drunk in } \\
\text { the past }\end{array}$ & 174 & 80.2 & 117 & 60.0 & 291 & 70.6 & \\
\hline Does not drink & 43 & 19.8 & 78 & 40.0 & 121 & 29.4 & \\
\hline Tobacco use & & & & & & & 0.002 \\
\hline $\begin{array}{l}\text { Smokes or has smoked } \\
\text { in the past }\end{array}$ & 85 & 39.2 & 48 & 24.7 & 133 & 32.4 & \\
\hline Does not smoke & 132 & 60.8 & 146 & 75.3 & 278 & 67.6 & \\
\hline Physical activity & & & & & & & 0.658 \\
\hline Active & 111 & 51.2 & 104 & 53.3 & 215 & 52.2 & \\
\hline Inactive & 106 & 48.8 & 91 & 46.7 & 197 & 47.8 & \\
\hline
\end{tabular}

Notes: Chi-square test; $\mathrm{n}=412$; *non-white individuals included those of indigenous race and those with black, brown, or yellow skin color; ${ }^{* *} \mathrm{~N}=4 \mathrm{I}$ I; ;lives with partner married or not; ${ }^{\S}$ does not live with a partner - single, separated, divorced, or widowed. tSocioeconomic class is classified on a scale ranging from A (highest) to $E$ (lowest) using the Economic Classification Criterion of Brazil, which assesses the presence and quantity of some household items and the level of education of the head of the household. Study undertaken in Vitória, Espírito Santo, Brazil, in 2016.

A total of $77.3 \%(n=68)$ of the 88 individuals with MS in the present study exhibited altered us-CRP levels, and this difference was significant $(P=0.0001$, confidence interval [CI]: 0.11-0.34). Figure 1 shows the serum levels of us-CRP in individuals with and without MS stratified by sex. Notably, individuals without MS exhibited lower us-CRP values than subjects with MS, in females $(P=0.004)$, males $(P=0.004)$, and the general MS population $(P=0.0001)$.

The prevalence of MS in analyses of the association of CRP levels into quartiles exhibited an upward trend of the prevalence of MS with increasing quartiles. However, this trend was not observed when the results were stratified by age (Figure 2).

Figure 3 shows an increasing trend of altered us-CRP levels with increasing criteria for MS. It is clear that normal 
A

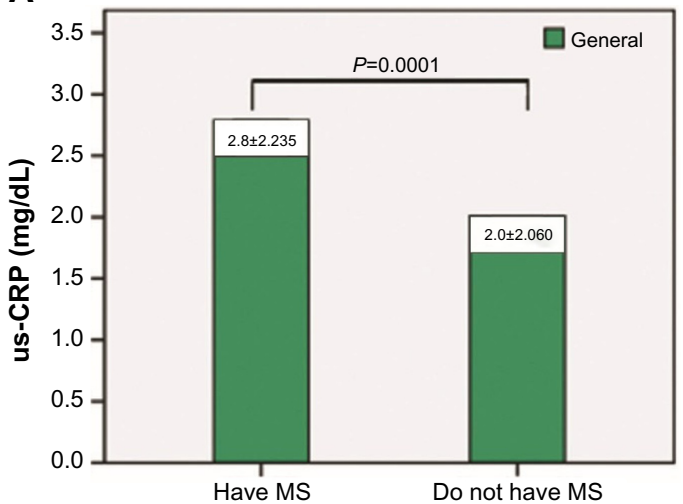

\section{B}

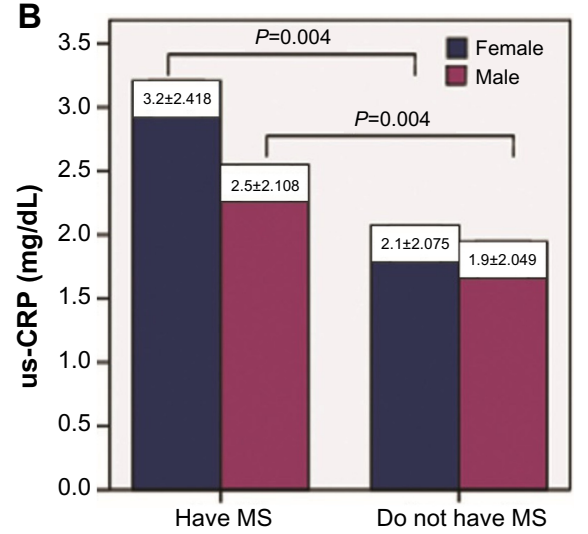

Figure I Serum levels of us-CRP in bank employees with and without MS stratified in general (A) and by sex (B).

Notes: Data are presented as the mean values. Study undertaken in Vitória, Espírito Santo, Brazil, in 2016.

Abbreviations: MS, metabolic syndrome; us-CRP, ultrasensitive C-reactive protein.

us-CRP levels tended to decrease with the presence of more criteria (on a scale $0-5$ ). Individuals with all five criteria for MS exhibited no change in us-CRP levels.

Figure 4 shows the frequency of the number of MS criteria and the average values of CRP stratified by sex. us-CRP levels increased in females and males with an increased number of MS criteria.
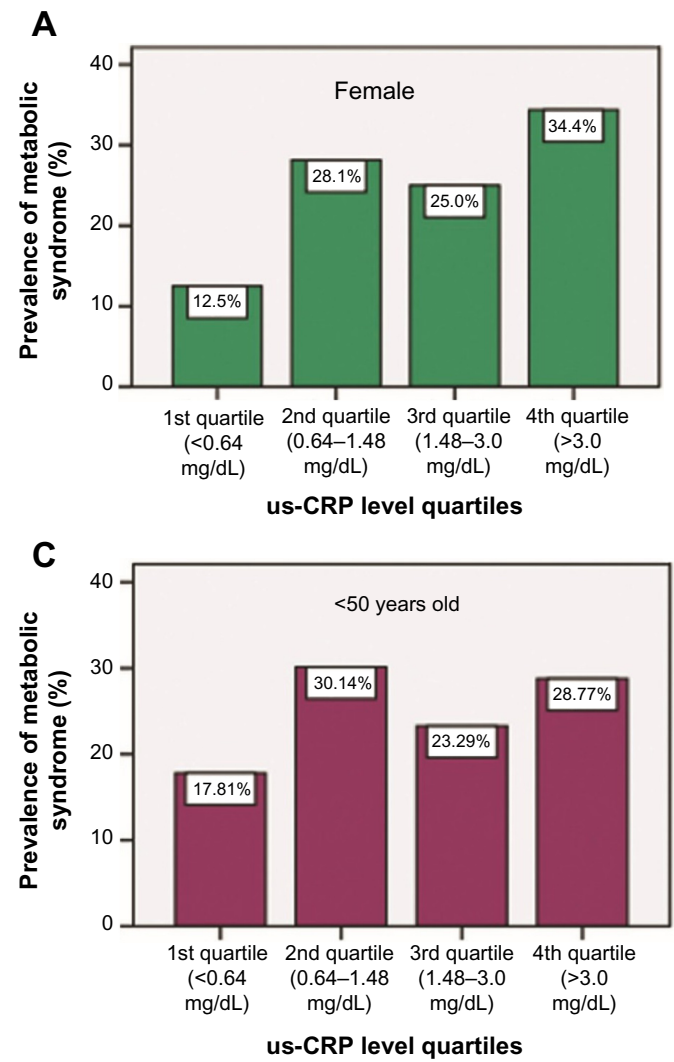

We also evaluated the association of us-CRP levels that were log-transformed with different socioeconomic variables and lifestyle habits. Smoking was associated with us-CRP; employees who smoked had higher mean us-CRP levels $(P=0.009)$. Other factors were not associated with us-CRP: age $(P=0.178)$, educational level $(P=0.987)$, race/ color $(P=0.921)$, marital status $(P=0.250)$, socioeconomic
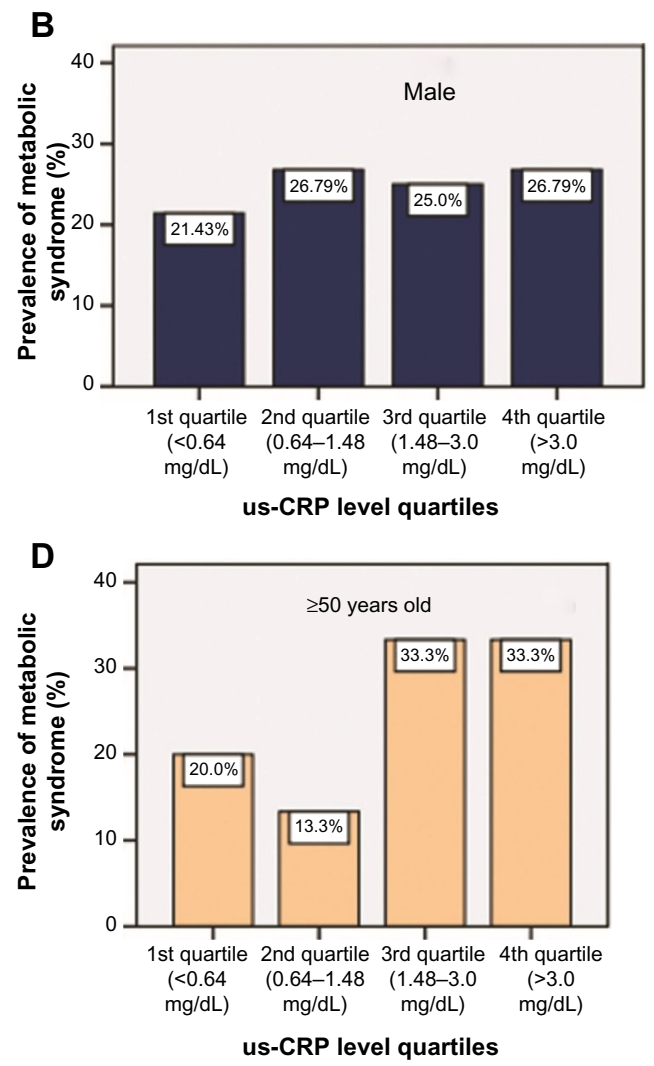

Figure 2 us-CRP level quartiles for bank employees according to the prevalence of MS stratified by sex (female $[\mathbf{A}]$ and male $[\mathbf{B}])$ and age $(<50$ years old $[\mathbf{C}]$ and $\geq 50$ years old [D]).

Note: Study undertaken in Vitória, Espírito Santo, Brazil, in 2016.

Abbreviations: MS, metabolic syndrome; us-CRP, ultrasensitive C-reactive protein. 


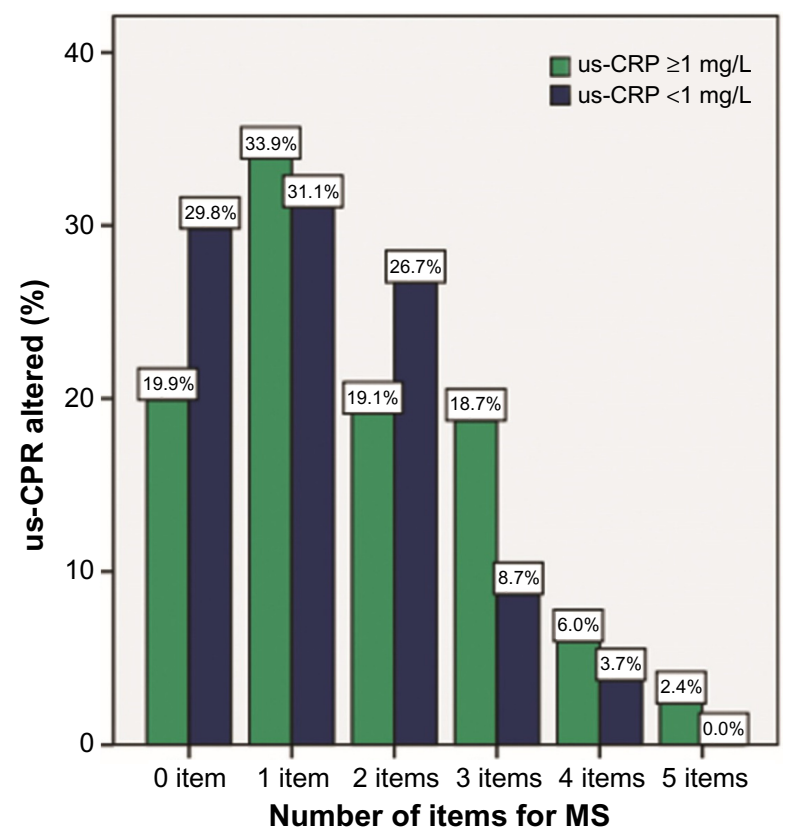

Figure 3 Frequency of the number of MS criteria and the percentage of altered us-CRP.

Note: Study undertaken in Vitória, Espírito Santo, Brazil, in 2016

Abbreviations: MS, metabolic syndrome; us-CRP, ultrasensitive C-reactive protein.

status $(P=0.934)$, hours of work per day $(P=0.426)$, alcohol consumption $(P=0.118)$, stress $(P=0.864)$, and physical activity $(P=0.764)$.

Figure 5 shows box plots of the behavior of MS criteria and the presence or absence of alterations in us-CRP levels.

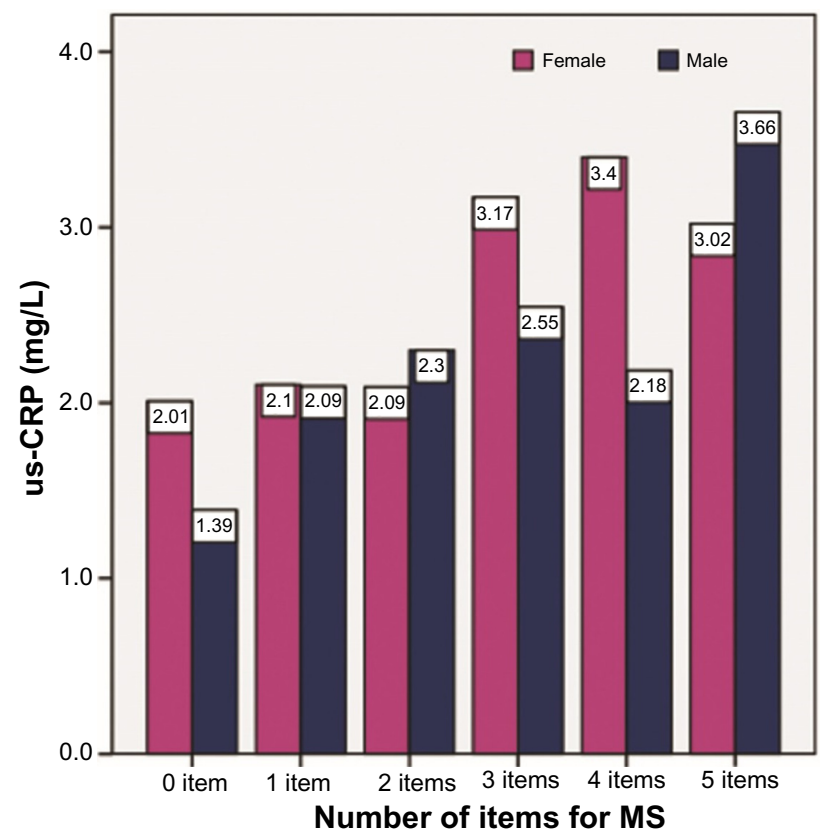

Figure 4 Frequency of the number of MS criteria and the average us-CRP values stratified by sex.

Note: Study undertaken in Vitória, Espírito Santo, Brazil, in 2016.

Abbreviations: MS, metabolic syndrome; us-CRP, ultrasensitive C-reactive protein.
One highest average trend in the variables was observed when us-CRP values were outside the normal range, and the following variables were significantly different: $\mathrm{PC}$ $(P=0.0001)$, TAG $(P=0.002)$, and DBP $(P=0.007)$. Spearman correlation analyses revealed that no variable had a medium or strong correlation, but $\mathrm{PC}(P=0.0001)$ and TAG $(P=0.000)$, SBP $(P=0.01)$, and DBP (0.0001) exhibited positive weak correlations.

\section{Discussion}

The present study demonstrated that 251 (60.9\%) of the 412 individuals studied exhibited changes in us-CRP levels. A total of $77.3 \%(n=68)$ of the 88 employees who had MS exhibited alterations in us-CRP levels, and this difference was significant ( $P=0.0001)$ compared to individuals without MS. This association demonstrates the capacity of us-CRP for predicting the risk of developing MS. We observed a trend of higher MS prevalence in the larger us-CRP quartiles of both sexes. Women $(P=0.004)$, men $(P=0.004)$, and individuals of both sexes $(P=0.0001)$ without MS exhibited lower us-CRP values than individuals with MS. Therefore, this variable is useful and effective to presume a risk of MS development in females and males regardless of age, in this group of workers.

MS is a growing concern worldwide because it is associated with cardiovascular comorbidities. Discrete elevations in us-CRP concentrations, even within the reference range, may predict the appearance of CVD and DM. ${ }^{9,12}$ us-CRP has received special attention because of its characteristic as a highly specific marker for coronary events and its potential role in pathogenesis. ${ }^{19}$

The general prevalence of MS in population-based study in Vitória, Espírito Santo was 29.8\% (95\% CI: $28 \%-32 \%$ ), with no difference between sexes. This study also identified a high prevalence of this syndrome in younger individuals, which may contribute to subsequent mortality during productive ages and following invalidity or retirement. ${ }^{3}$ This result demonstrates the importance of us-CRP as a marker to predict and monitor the development of MS in a population, which includes our results in bank employees. The productive restructuring process and globalization of the market economy cause significant impacts on the conditions of employment and wages, as well as the health of workers, ${ }^{20}$ especially in the profession of banking, which is recognized for being highly affected by work diseases due to its extremely hectic routine, in which anxiety and haste can influence their health standards. ${ }^{21}$ 
A

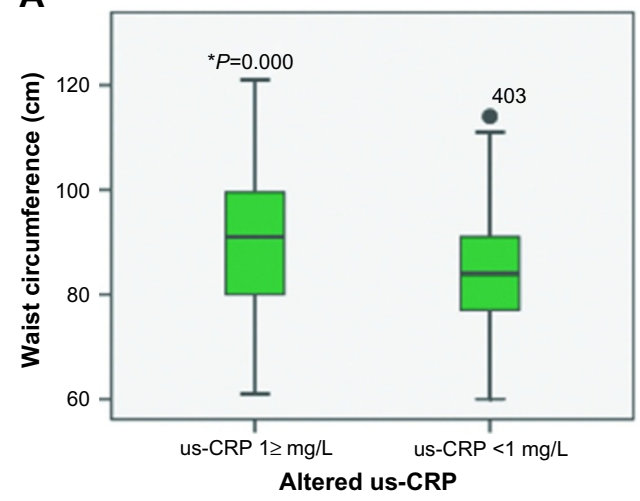

\section{C}

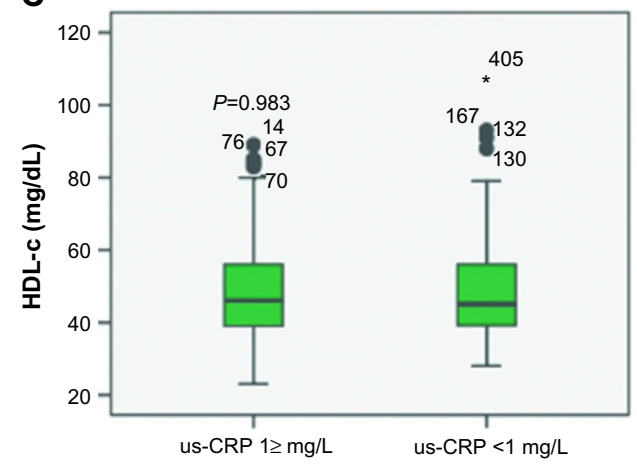

Altered us-CRP

E

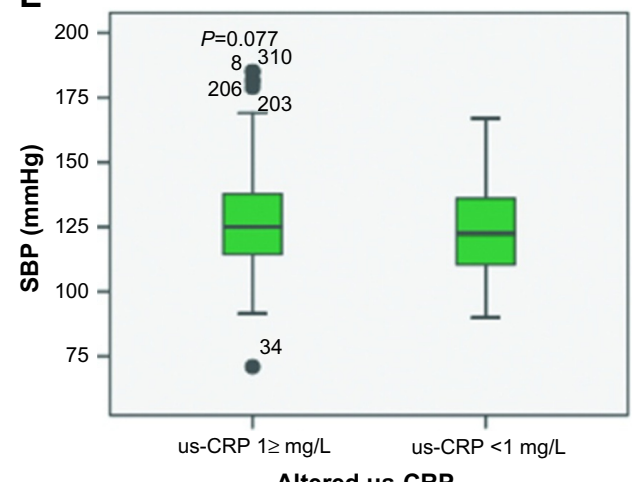

B

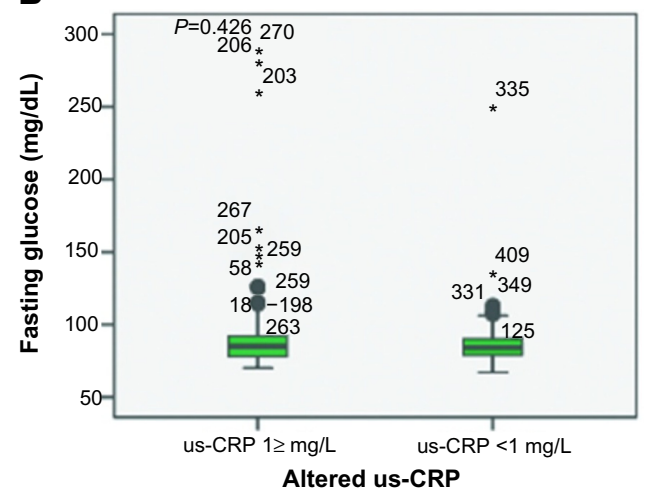

D

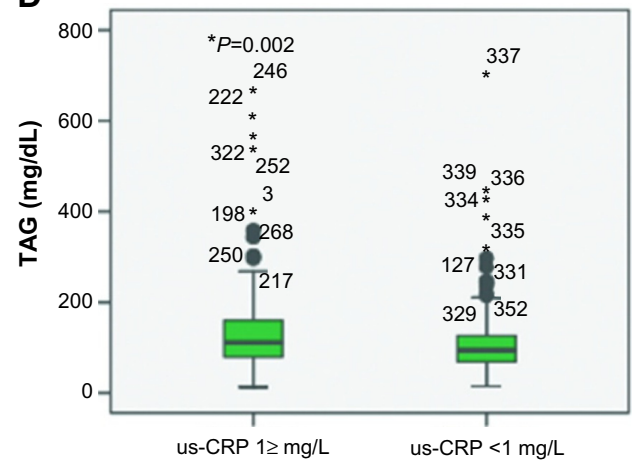

Altered us-CRP

$\mathbf{F}$

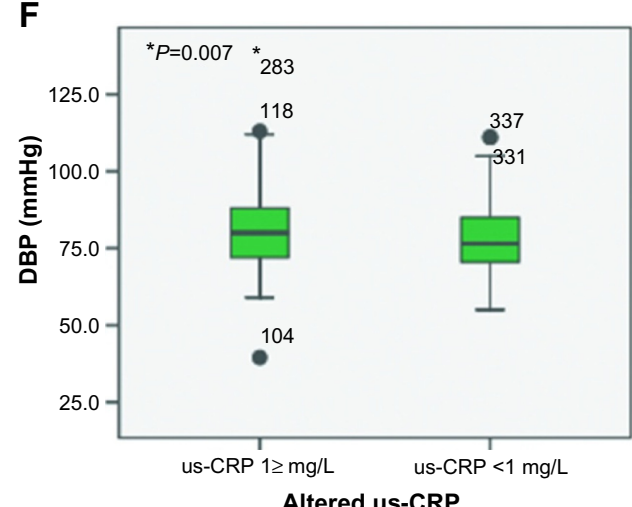

Figure 5 Behavior of MS criteria according to altered us-CRP versus normal us-CRP.

Notes: (A) Waist circumference; (B) fasting glucose; (C) HDL-c; (D) TAG; (E) SBP; and (F) DBP. Student's t-test for independent samples was used for A, E, and F. Mann-Whitney $U$ test was used for B, C, and D. Values indicated with “*” are the outliers; P-values shown with "*” are significant; $P$-values shown without "*” are not significant. Study undertaken in Vitória, Espírito Santo, Brazil, in 2016.

Abbreviations: DBP, diastolic blood pressure; HDL-c, high-density lipoprotein cholesterol; MS, metabolic syndrome; SBP, systolic blood pressure; TAG, triglycerides; usCRP, ultrasensitive C-reactive protein.

The median us-CRP of our study of bank employees was similar to previous studies, such as the secondary analysis of the Encuesta Nacional de Salud (ENSA) 2000 data, in which the median CRP level was $2.26 \mathrm{mg} / \mathrm{dL} .{ }^{20}$ However, the study by Silva et $\mathrm{al}^{2}$ in Inhaumas (Santa Maria da Vitória, Bahia, Brazil) reported a lower average CRP value $(1.8 \mathrm{mg} / \mathrm{dL})$, which is similar to a study of patients from a public hospital in a province of Buenos Aires, Argentina (2012), in which the median CRP concentration was $1.3 \mathrm{mg} / \mathrm{dL}{ }^{6}$
We emphasize the association of MS criteria with CRP values and quartiles. Silvia et $\mathrm{al}^{6}$ also observed that CRP levels rose with an increased number of MS components.

The criteria for MS in the present study of bank employees that exhibited some association with us-CRP levels were TAG, SBP, and waist circumference. These criteria were also examined in a study in the communities of Virgem das Graças and Caju, Vale do Jequitinhonha, Minas Gerais, Brazil, and age, SBP and DBP, body mass index, PC, TAG, total cholesterol, 
and low-density lipoprotein cholesterol positively correlated with CRP. Education and HDL-c variables were inversely correlated with CRP levels ${ }^{9}$. Flores et $\mathrm{al}^{22}$ demonstrated that CRP concentrations were positively associated with age, fasting glucose, hypertension, DM, body mass index, PC, and PAS. However, menopause, alcohol consumption, and smoking were not related. Similarly, Zeba et $\mathrm{al}^{23}$ reported that us-CRP levels in Ouagadougou (Burkina Faso's capital, a country in Sub-Saharan Africa) were significantly different between subjects who exhibited overweight, abdominal obesity, high fat percentage body, more criteria for MS, high low-density lipoprotein cholesterol, low HDL-c, and high TAG only in women $(P=0.049)$.

Very similar data to our study of bank employees were found in a semirural suburb in the city of Camaçari/BA/BR, in which the group had a low education and low monthly income, which is the opposite of the current study. The median level of us-CRP in Camaçari was $2.0 \mathrm{mg} / \mathrm{dL}$. Overweight individuals showed higher us-CRP levels than individuals with normal weight, smokers, and hypertensive individuals. us-CRP levels were not associated with sex, ethnicity, education level, income, physical activity, or DM. ${ }^{10}$

The association of CRP with the excess body fat, overweight, abdominal obesity, and elevated TAG levels may be associated with the metabolic character of the adipose tissue. Adipose tissue is responsible for the production of $\sim 30 \%$ of the proinflammatory cytokine interleukin- 6 (IL-6). Adipocytes also express tumor necrosis factor $\alpha$ (TNF- $\alpha$ ) and IL-1. CRP synthesis occurs in the liver, and it is primarily modulated by IL-6, although IL- 1 and TNF- $\alpha$ also participate in this modulation. Therefore, the resulting increase in these proinflammatory cytokines from adipose tissue leads to an increase in hepatic synthesis of CRP. The presence of insulin inhibits CRP and cytokine production mechanisms, but the insulin resistance state leads to a failure of this control mechanism by increasing the synthesis of hepatic CRP. ${ }^{6,9,11}$

Other socioeconomic variables and lifestyle habits, in addition to MS criteria, were also analyzed. Only smoking was associated with CRP levels. Individuals who smoked had a higher average us-CRP concentration $(0.009 \mathrm{mg} / \mathrm{dL}$, $P=0.002)$. Other factors were not associated with us-CRP levels.

A study of the Virgem das Graças and Caju communities revealed no association between smoking and serum CRP levels. ${ }^{9}$ However, tobacco distribution showed a significant positive association with CRP levels in Pelotas/BR but only in men. ${ }^{19}$
We observed no distinction between polymeric and monomeric us-CRP, and our sample was limited to a specific group of working bank employees. However, we can investigate this variable in other population groups based on the result of our group.

This study of bank employees identified an association of us-CRP levels with the presence of MS. We also observed that us-CRP was a useful and effective variable to predict the risk of developing MS. The connection of this variable and the number of criteria for MS was also clear because us-CRP levels increased in the presence of more MS factors, and the us-CRP levels in normal individuals decreased. The same trend was noted in quartiles of us-CRP in the presence of MS.

\section{Conclusion}

The measurement of serum us-CRP levels is easily used to detect subclinical and clinical inflammation, and these levels revealed an increased risk of cardiovascular events. The early detection of altered us-CRP is an interesting marker because it would be possible to implement therapeutic and prophylactic measures quickly. The determination of us-CRP levels is simple and accessible for any laboratory of average complexity.

Therefore, these results support the realization of the us-CRP test in routine care as a marker to predict the risk of complications of MS and other cardiovascular comorbidities, such as hypertension and dyslipidemia. Further studies can investigate the possible inclusion of this marker to the classification criteria of MS because of the strong association we observed in this group of workers.

\section{Acknowledgment}

The authors thank the entire staff of the Banco do Estado do Espírito Santo who contributed to this research.

\section{Disclosure}

The authors report no conflicts of interest in this work.

\section{References}

1. Sociedade Brasileira de Hipertensão. I Diretriz Brasileira de Diagnóstico e Tratamento da Síndrome Metabólica. [I Brazilian Guideline for the diagnosis and treatment of metabolic syndrome]. Arquivos Brasileiros de Cardiologia. 2004;84 (Suppl 1):1-28. Portuguese.

2. Silva KF, Prata A, Cunha DF. Frequency of metabolic syndrome and the food intake patterns in adults living in a rural area of Brazil. Rev Soc Bras Med Trop. 2011;44(4):425-429.

3. Salaroli LB, Barbosa GC, Mill JG, Molina MC. Prevalência de Síndrome Metabólica em Estudo de Base Populacional, Vitória, ES - Brasil. [Prevalence of metabolic syndrome in population-based study, Vitória, ES - Brazil]. Arq Bras Endocrinol Metab. 2007;51(7):1143-1152. Portuguese. 
4. Ford ES. Prevalence of the metabolic syndrome defined by International Diabetes Federation among adults in the US. Diabetes Care. 2005;28(11):2745-2749.

5. Arnaiz P, Arnaldo M, Felipe P, et al. Índice cintura estatura y agregación de componentes cardiometabólicos em niños y adolescentes de Santiago. [Waist height ratio, ultrasensitive $\mathrm{C}$ reactive protein and metabolic syndrome in children]. Rev Med Chil. 2010;138:1378-1385. Spanish.

6. Silvia F, Fernando P, Graciela LP, et al. Proteína C reactiva: un marcador bioquímico associado com el síndrome metabólico y la obesidad abdominal. [C-reactive protein: a biomarker associated with the metabolic syndrome and abdominal obesity]. Rev Argent Cardiol. 2012;80:456-460. Spanish.

7. Lakka HM, Laaksonen DE, Lakka TA, et al. The metabolic syndrome and total and cardiovascular disease mortal in middle-aged men. JAMA. 2002;288(21):2709-2716.

8. Figueiroa PR, Hamad I, Pascual Garcí FJ, Carazo Marín AF, Casado Almeida MA, Forcada AG. Proteína C Reactiva em el pronóstico de la insuficiencia cardíaca. [C-reactive protein in the prognosis of heart failure]. Rev Costarr Cardiol. 2007;9(2):5-10. Spanish.

9. Fernandes AC, Gazzinelli A, Velásquez-Meléndez G. Associação entre medidas de adiposidade, variáveis demográficas e bioquímicas com os níveis séricos de proteína C-reativa em população rural. [Association between adiposity measures, demographic and biochemical variables with C-reactive protein serum levels in rural population]. Arch Latinoam Nutr. 2009;59(1):54-60. Portuguese.

10. Correia LCL, Penalva R, Correia H. Determinantes do Valor da Proteína C-reativa em Indivíduos de Nível Sócio-Econômico Muito Baixo. [Determinants of C-reactive protein in individuals with very low socioeconomic status]. Arq Bras Cardiol. 2010;94(2):216-223. Portuguese.

11. Brasil AR, Rocksane CN, Rossetti MB, Leão RPM. Proteína C reativa como indicador de inflamação de baixa intensidade em crianças e adolescentes com e sem obesidade. [C-reactive protein as an indicator of low intensity inflammation in children and adolescents with and without obesity]. J Pediat. 2007;83(5):477-480. Portuguese.

12. Salaroli LB, Saliba RA, Zandonade E, Molina MC, Bissoli NS. Prevalence of metabolic syndrome and related factors in bank employees according to different defining criteria, Vitória/ES, Brazil. Clinics. 2013;68(1):69-74.

13. Sasaki JE, Krause MP, Gama MP, et al. Influência da Adiposidade Global e da Adiposidade Abdominal nos Níveis de Proteína C-Reativa em Mulheres Idosas. [Influence of overall and abdominal adiposity on C-reactive protein levels in elderly women]. Arq Bras Cardiol. 2007;89(4):231-236. Portuguese.
14. Sociedade Brasileira de Cardiologia/Sociedade Brasileira de Hipertensão/Sociedade Brasileira de Nefrologia. VI Diretrizes Brasileiras de Hipertensão. [VI Brazilian Guidelines on Hypertension]. Arq Bras Cardiol. 2010; 95(1 Suppl 1):1-51. Portuguese.

15. World Health Organization. Physical Status: the Use and Interpretation of Anthropometric Indicators of Nutritional Status. Geneva: World Health Organization; 1995.

16. Mendes LL, Gazzinelli A, Velásquez-Meléndez G. Fatores associados à resistência à insulina em populações rurais. [Factors associated with insulin resistance in rural populations]. Arq Bras Endocrinol Metab. 2009;53(3):332-339. Portuguese.

17. NCEP/ATP III. Expert panel on detection, evaluation, and treatment of high blood cholesterol in adults. Executive summary of the third report of the National Cholesterol Education Program (NCEP) Expert Panel on Detection, Evaluation, and treatment of high blood cholesterol in adults (Adult Treatment Panel III). JAMA. 2001;285(19):2486-2497.

18. Pearson TA, Mensah GA, Alexander W, et al. Markers of inflammation and cardiovascular disease: application to clinical and public health practice. A statement for health care professionals from the Centers for Disease Control and Prevention and the American Heart Association. Circulation. 2003;107:499-511.

19. Nazmi A, Oliveira IO, Victora CG. Correlates of C-reactive protein levels in young adults: a population-based cohort study of 3827 subjects in Brazil. C-reactive protein in a Brazilian birth cohort. Braz J Med Biol Res. 2008;41:357-367.

20. Jinkings N. Os trabalhadores bancários em face a reestruturação do capitalismo contemporâneo. [Bank workers in the face of restructuring of contemporary capitalism]. Cad pesq. 2001;28:1-21. Portuguese.

21. Araújo MP, Costa-Souza J, Trad LA. A alimentação do trabalhador no Brasil: um resgate da produção científica nacional. [Worker diet in Brazil: a review of Brazilian scholarship on the topic]. Hist Ciênc Saúde-Manguinhos. 2010;17(4):975-992. Portuguese.

22. Flores M, Barquera S, Carrión C, et al. Concentraciones de proteína $C$ reactiva en adultos mexicanos: alta prevalência de unfactor de riesgo cardiovascular . [C-reactive protein concentrations in Mexican men and women: high prevalence of a cardiovascular risk factor]. Salud pública de México. 2007;49(3):348-360. Spanish.

23. Zeba AN, Delisle HF, Rossier C, Renier G. Association of highsensitivity C-reactive protein with cardio metabolic risk factors and micronutrient deficiencies in adults of Ouagadougou, Burkina Faso. Br J Nutr. 2013;109:1266-1275.

\section{Publish your work in this journal}

Diabetes, Metabolic Syndrome and Obesity: Targets and Therapy is an international, peer-reviewed open-access journal committed to the rapid publication of the latest laboratory and clinical findings in the fields of diabetes, metabolic syndrome and obesity research. Original research, review, case reports, hypothesis formation, expert opinion and commentaries are all considered for publication. The manuscript management system is completely online and includes a very quick and fair peer-review system, which is all easy to use. Visit http://www.dovepress.com/testimonials.php to read real quotes from published authors. 